\title{
Ambiguity Aversion and Mutual Funds: Evidence from China
}

\author{
Yuxiang Bian ${ }^{1}$ \\ ${ }^{1}$ Business School, East China University of Political Science and Law, Shanghai, 201620, China \\ Correspondence: Yuxiang Bian, Business School, East China University of Political Science and Law, Shanghai, \\ 201620, China. E-mail: brianbian912@163.com
}

Received: October 1, 2021

Accepted: November 20, 2021

Online Published: November 22, 2021

doi:10.5539/ijbm.v16n12p111

URL: https://doi.org/10.5539/ijbm.v16n12p111

\begin{abstract}
I provide empirical evidence of ambiguity averse investors' behaviour in China's mutual funds market. My analysis is motivated by the substantial uncertainty in China's mutual funds market, and theoretical research of decision indicates that investors would be more ambiguity averse when face higher uncertainty. The most substantial implication of the empirical research is that investors tend to place more weight on the worst signal. Across multiple horizons, fund flows will also display more sensitivity to the worst performance. I also conduct robustness test about the different rank funds by Morningstar rating and compare the positive and negative performance during the minimum performance period.
\end{abstract}

Keywords: Ambiguity averse, mutual funds, China's financial market

\section{Introduction}

Unlike the financially developed markets in the world, China's financial market is still developing and immature, and the investors in China still choose to take time and fortune to invest by themselves without protest. However, the global financial crisis in 2008 and the 2015 China financial crash changed this situation to some extent. Individual investors are eager to find good performance and reliable funds can earn a consistent profit and have excess return compared to the whole stock market. Thus the number of mutual funds in China has grown substantially during the last ten years. In emerging market funds, many of which have a heavy weighting to China, In March 2019, MSCI, the index provider, included Chinese stocks in its popular emerging markets benchmark, which is followed by about $\$ 1.9$ tn in assets. Investment company tries to create diversification potential and impressive performance funds to meet the dynamic needs of investors (Polwitoon \& Tawatnuntachai, 2006, 2008). For individual investors, investing in mutual funds is a convenient way of getting excess return and avoiding system and idiosyncratic financial risk.

However, the financial market in China is becoming more and more complicated with the development of the overall economy over 30 years of reform. The investing environment requires investors to process large amounts of information while making decisions ( $\mathrm{Li}$, Tiwari and Tong, 2016). In the Chinese asset management industry, the depreciating currency, capital control, the tariff problems, these interrelated issues with the slowing economy and choppy equity markets will have an uncertain effect on the profitability of Chinese companies. When investors are facing unknown quality information signals, they will regard these signals as ambiguity signals (Epstein and Schneider 2008). In another aspect, evidence from the laboratory and experimental field have proved that people are ambiguity averse (Bossaerts, Ghirardato, Guarnaschelli, \& Zame, 2010, Ahn, Choi, Gale \& Kariv, 2014; Dimmock, Kouwenberg, Mitchell, \& Peijnenburg, 2016). That means, once risk-neutral investors get common and enough knowledge of the financial and capital market, they will have enough courage to invest. But if the investors face ambiguity about the prospect of the financial market, not knowing the exact states of nature, they will choose short positions even zero position in the asset they are ambiguous about. Considerable theoretical literature has incorporated ambiguity into investments and the investors will become less willing to participate when ambiguity increases (Cao, Wang \& Zhang, 2005; Dow \& da Costa Werlang, 1992; Epstein \& Schneider, 2007, 2008, 2010).

The choosing of good performance phenomenon of mutual funds investors suggested a natural link between performance-related information and decisions of investors. Thus the flow into and out of mutual funds is an appropriate reflection of investors' decisions. However, the financial system in China is underdeveloped compared with the rapid economic growth during the past few decades. The change of invest environment and 
fluctuations in policy background will force the investors in China's financial market to face more ambiguity compare to the developed financial system, thus mutual fund is one important component of China's financial market. Facing the uncertainty and ambiguity about the investment in the future, the ambiguity averse investors will highly rely on the historical fund performance information (Lynch \& Musto, 2003). The performance information will serve as signals to investors about the mutual fund managers' skill. However, the signals investors faced to contain a great deal of uncertainty about the quality of performance. Thus to study how the ambiguity averse investors response to different and various signals about the performance information is essentially important and high relative to the investment strategy in daily life, especially in China's financial market.

In this paper, I try to provide novel and empirical evidence about the effect of ambiguity aversion in the decision of the investors' response to China's mutual funds. The key implication and conclusion of my analysis are that when investors face uncertain quality performance signals, they will place the greatest weight on the worst signal. This corresponds to the motivation theoretical research by Epstein and Schneider (2008), Klibanoff, Marinacci and Mukerji (2005) and Ju and Miao (2012). The result of my analysis indicate that ambiguity averse investors are more sensitive to the worst-scenario. Motivated by Antoniou, Harris and Zhang (2015), Huang, Wei and Yan (2007) and Li, Tiwari and Tong (2016), I use net fund flows as a proxy of China's mutual fund investors' decisions. Since the percentage of individual investors in China's mutual funds market is much higher than the developed markets, I examine the sensitivity of fund flows over these time-multiple horizons: quarter, six months, one year, three years. I compare performance in these multiple horizons to serve as multiple signals and decide the relative worst performance. I try to provide some answers to the problem about how do ambiguity-averse investors interpret and response to uncertainty signals. My research indicates that investors tend to be more sensitive to the worst-scenario case, which means bad time performance will place more ambiguous to the investors. Especially, when I control the ranking of mutual funds to low period, the investors will display more sensitivity to the fund flows. The phenomenon shows that the degree of ambiguity aversion and sensitivity are different across different mutual funds.

This paper contributes to the literature about non-experimental and empirical research about investors' ambiguity averse investment behaviour. There is growing literature focus on the decision under ambiguity aversion in financial markets. Chen and Epstein (2002), Ahn, Choi, Gale and Kariv (2014), Dimmock, Kouwenberg, Mitchell and Peijnenburg (2016) and a large amount of literature finds that investment subjective is ambiguity averse with unknown probabilities for the future, and many theoretical models predict that ambiguity could decrease investors' willingness to invest (Cao, Wang and Zhang, 2005, Klibanoff, Marinacci and Mukerji, 2005 and Easley and O'Hara, 2009).

Next, my paper also has a contribution to the literature about the mutual funds' performance under uncertainty environment. Carhart (1997) conducted a four-factor empirical method to study the persistence in mutual funds performance. Cremers and Petajisto (2009) develop a new measure that predicts mutual funds performance with the view of the activeness of the fund managers. Froot, Oconnell and Seasholes (2001) and Kacperczyk and Seru (2007) find that the management ability of fund managers and fund's historical performances can significantly affect the fund flows. Del Guercio and Tkac (2008) indicates that star funds can attract investment in the market and rating of funds also matters considering the low fund search costs. My paper supplements this literature with the study indicating that investors' behaviour sensitivity can influence the fund flows.

However, the focus of China's financial market investors' ambiguity averse is limited. Huang, Wei and Yan (2012) showed fund investors' sensitivity to past performance is decreasing with the increasing return volatility. But their focus is on the US mutual funds market, and it is much different from China's financial market due to the more complicated and complex characters of China's financial market. My study helps address this gap in the literature.

The remainder of this paper is structured as follows: Section 2 presents the Data and Methodology. The third section presents the empirical evidence and explanations. Section 4 concludes the paper.

\section{Data and Methodology}

\subsection{Data}

I focus on the actively managed China's equity mutual funds and I exclude the index and QDII funds. To be consistent with prior empirical research about mutual funds (Sialm, Starks, \& Zhang, 2015, Sirri \& Tufano, 1998). I also exclude sector funds, international funds and bond funds in my analysis. Data of mutual funds is all from RESSET database. Considering two aspects, the number of mutual funds in China is less than 100 before 2015, and from the third quarter in 2015 to the first quarter in 2016, big financial market crash taken place in 
China. Due to these two subjective reasons, my study focus on the period from the July 2016 to December 2018, and I confirm fund flows and other characteristics at the quarterly frequency.

Following Li, Tiwari and Tong (2016), I measure fund flows as relative total net asset value changes:

$$
\text { Flow }_{i, t}=\frac{\text { TNA }_{i, t}-\mathrm{TNA}_{\mathrm{i}, \mathrm{t}-1}\left(1+\mathrm{R}_{\mathrm{i}, \mathrm{t}}\right)}{\mathrm{TNA}_{\mathrm{i}, \mathrm{t}-1}},
$$

where $R_{i, t}$ denotes fund i's return during quarter $\mathrm{t}$, and $T N A_{i, t}$ indicates the fund's total net asset value at the end of quarter t. Thus essentially, the definition of this fund flows reflects the percentage growth of the total fund assets in quarter t. We filter out the top and bottom $1 \%$ tails of the net flow data in order to avoid outliers.

\subsection{Empirical Methodology}

In the analysis, I analyze the correlation between mutual fund flows and performance measured over multiple horizon in China's financial market. Follwing Sirri and Tufano (1998), I construct a panel linear regression during the period of the sample to test the relation ambiguity and fund flows:

$$
\text { Flow }_{i, t}=a+b_{1} \operatorname{Perf}_{i, t}^{q u a}+b_{2} \operatorname{Perf}_{i, t}^{6 m}+b_{3} \operatorname{Perf}_{i, t}^{1 y r}+b_{4} \operatorname{Perf}_{i, t}^{3 y r}+\text { cMin_Rank }_{i, t}+\text { Controls }+\epsilon_{i, t} .
$$

The variables $\operatorname{Perf}_{i, t}^{q u a}, \operatorname{Perf}_{i, t}^{6 m}, \operatorname{Perf}_{i, t}^{1 y r}, \operatorname{erf} f_{i, t}^{3 y r}$ represents fractional performance ranks from 0 to 1 based on the fund i's performance during 1 quarter, 6 months, 12 months and 36 months, respectively. In addition, the variable $M i n \_R a n k_{i, t}$ is defined as:

$$
\operatorname{Min} \_R a n k_{i, t}=\operatorname{Min}\left(\operatorname{Perf}_{i, t}^{q u a}, \operatorname{Perf}_{i, t}^{6 m}, \operatorname{Perf} f_{i, t}^{1 y r}, \operatorname{Perf}_{i, t}^{3 y r}\right) \text {. }
$$

Thus the coefficient $c$ in my model represents the additional flow sensitivity to performance measured over the horizon during which the fund had the worst performance ranking. As the empirical results I show below, the additional flow-performance sensitivity coefficient $\mathrm{c}$ is significant in both economic and statistical sense.

In this paper, the control variables in equation (2) include the funds characteristics that may affect the fund flows. Following Li, Tiwari and Tong (2016) and Antoniou, Harris and Zhang (2015), I control for the logarithm of on plus fund age and previous fund quarter's flow. I also compare the results of different types of the equity mutual funds, with the quarterly rank results of Morningstar, Inc in China's mutual funds.

\section{Empirical results}

Table 1 reports the summary statistics of mutual funds characteristics in China's financial market. In this paper, I use this table to present the time-series average of the panel mean, standard deviation, 25th percentile (p25), 75th percentile (p75), min and max of these fund characteristics. Compared the results of (Li, Tiwari and Tong, 2016), I can figure out that the average age of China's mutual funds 7.082 is much smaller than US mutual funds market 13, and that's the reason I didn't chose 5 years performance as the control variable. In another aspect, the average flow of China's mutual funds market is negative while the US market is positive, from the intuitive understanding, that means the development and prospect of US mutual funds market is much steadier than China's market.

Table 1. Summary statistics of China's mutual funds.

\begin{tabular}{llllll}
\hline & $(1)$ & $(2)$ & $(3)$ & $(4)$ & $(5)$ \\
VARIABLES & mean & sd & p25 & median & P75 \\
\hline TNA(in millions) & 1332 & 2.971 & 1120 & 1204 & 1660 \\
return1(per quarter) & -0.00248 & 0.0519 & -0.0210 & -0.0210 & 0.0177 \\
return2(per & -0.00345 & 0.0839 & -0.0308 & -0.0308 & 0.0274 \\
6months) & & & & & \\
return3(per year) & 0.00270 & 0.123 & -0.0354 & -0.0354 & 0.0485 \\
return4(per3 years) & 0.0555 & 0.0912 & 0.0198 & 0.0198 & 0.100 \\
flow & -0.0180 & 0.0290 & -0.0375 & -0.0375 & 0.000574 \\
age & 7.082 & 3.392 & 4.208 & 4.208 & 9.060 \\
Return Volatility & 0.158 & 0.134 & 0.0315 & 0.0315 & 0.282 \\
Companycode & 2201 & 2201 & 2201 & 2201 & 2201 \\
Number & & & & & \\
\hline
\end{tabular}

In the circumstance of real investment, the investors receive the signals conveying either good or bad news, the 
news could be highly related and precise to the investors' choice, but the signals could also be noisy and not informative. The investors want to make a robust decision to this uncertainty, thus they pay the most attention to the worst scenario (Illeditsch, 2011). I predict that due to the investors' ambiguity aversion, fund flows will display additional sensitivity to the response of past performance measures. To test this prediction, I use the baseline model equation (3) to estimate the regression parameters. Like Sirri and Tufano (1998) mentioned, the impact of volatility on flows should be negative, which means the volatility will also have a negative effect on China's mutual funds flows. From columns (1) to (5) in Table 2, I add the performance measures variables step by step to get the precise and conservative estimation. The parameter of Perf qua is always positive and significant no matter considering which model. It is intuitive because the uncertainty of China's financial market is much higher than the US and European financial markets, thus the investors in China's mutual funds become more sensitive and more willing to make the short term investment. After incorporating the one year and three years performance measures into the regression model, we can find that the coefficient of one-year performance is significant while the coefficient of three years performance is only significant in column (5) regression. This is also corresponding to the findings, Since the degree of China's mutual funds uncertainty is much higher, the investors are not willing to hold a long term position of the same fund.

Table 2. Investors' flow-performance sensitivity

\begin{tabular}{|c|c|c|c|c|c|}
\hline & (1) & (2) & (3) & (4) & (5) \\
\hline VARIABLES & Model 1 & Model 2 & Model 3 & Model 4 & Model 5 \\
\hline \multirow[t]{2}{*}{ Perf qua } & $0.0217 * * *$ & $0.0222 * * *$ & $0.0226 * * *$ & $0.0225 * * *$ & $0.0223 * * *$ \\
\hline & $(0.000899)$ & $(0.00124)$ & $(0.00125)$ & $(0.00126)$ & $(0.00131)$ \\
\hline \multirow[t]{2}{*}{$\operatorname{Perf} f^{6 m}$} & & $0.000797 *$ & $0.000413 *$ & $0.000508^{* *}$ & $0.000670 * *$ \\
\hline & & $(0.00135)$ & $(0.00143)$ & $(0.00145)$ & $(0.00145)$ \\
\hline \multirow[t]{2}{*}{$\operatorname{Perf} f^{1 y r}$} & & & $0.00244 * *$ & $0.00249 * *$ & $0.00300 * *$ \\
\hline & & & $(0.000986)$ & $(0.000991)$ & $(0.00144)$ \\
\hline \multirow[t]{2}{*}{ Perf $f^{3 y r}$} & & & & 0.000732 & $0.000812 *$ \\
\hline & & & & $(0.00133)$ & $(0.00140)$ \\
\hline \multirow[t]{2}{*}{ Rank } & & & & & $0.001986^{* * *}$ \\
\hline & & & & & $(0.00129)$ \\
\hline \multirow[t]{2}{*}{ Age } & -0.00417 & -0.00402 & -0.00453 & -0.00495 & $-0.00520^{*}$ \\
\hline & $(0.00292)$ & $(0.00294)$ & $(0.00294)$ & $(0.00304)$ & $(0.00308)$ \\
\hline \multirow[t]{2}{*}{ Flow previous quarter } & $0.0618 * * *$ & $0.0621 * * *$ & $0.0628 * * *$ & $0.0629 * * *$ & $0.0628 * * *$ \\
\hline & $(0.00511)$ & $(0.00515)$ & $(0.00516)$ & $(0.00516)$ & $(0.00516)$ \\
\hline \multirow[t]{2}{*}{ Volatility } & $-0.132 * * *$ & $-0.133^{* * *}$ & $-0.132 * * *$ & $-0.130 * * *$ & $-0.130 * * *$ \\
\hline & $(0.00965)$ & $(0.00974)$ & $(0.00975)$ & $(0.0104)$ & $(0.0104)$ \\
\hline \multirow[t]{2}{*}{ Constant } & $-0.0401 * * *$ & $-0.0404 * * *$ & $-0.0389 * * *$ & $-0.0380 * * *$ & $-0.0373 * * *$ \\
\hline & $(0.00682)$ & $(0.00684)$ & $(0.00686)$ & $(0.00706)$ & $(0.00718)$ \\
\hline Observations & 13,779 & 13,779 & 13,779 & 13,779 & 13,779 \\
\hline R-squared & 0.106 & 0.106 & 0.107 & 0.107 & 0.107 \\
\hline Companycode Number & 2201 & 2201 & 2201 & 2201 & 2201 \\
\hline
\end{tabular}

Notes. ${ }^{* * *} \mathrm{p}<0.01, * * \mathrm{p}<0.05, * \mathrm{p}<0.1$. Standard errors in parentheses.

Next, I focus on the coefficient $\mathrm{c}$ of variable Rank to interpret the economic findings, this coefficient is the most focus of the empirical analysis. This $\mathrm{c}$ in this model captures the additional flow sensitivity performance measured over the particular horizon during which the fund had the worst performance ranking. Since parameter $\mathrm{c}$ is the minimum performance measure over multiple horizons in the presence of ambiguity-averse investors, in the empirical results, we expect to see the additional flow-performance sensitivity parameter $\mathrm{c}$ is significant with both economic and statistical aspects, and the regression result show that the coefficient for Rank is positive and significant at the $1 \%$ level, which corresponds to the prediction. Thus we get the similar conclusion with some theoretical models of decision making under ambiguity (e.g., Epstein and Schneider, 2007, 2008, 2010), when faced with signals of uncertain quality, fund flows display high sensitivity to the minimum performance measure and the investors in China's mutual funds market tend to place a greater weight on the worst signal.

\subsection{Further Analysis and Robustness Test}

We need to examine the robustness of the key empirical findings of the sensitivity of fund flows to the worst 
performance signal. The robustness check will help us to confirm that the results and implications are robust for flow-performance relation and other accounting performance-related information. In this paper, I choose Morningstar funds Ratings of China's mutual funds market as the control variable in the robustness test.

Morningstar company rates all China's equity mutual funds based on their monthly, quarterly and yearly performance, return and risk, and then a weighted overall rating is determined. I download the Morningstar funds Ratings of China's equity mutual funds market through the RESSET database. With the Morningstar funds Ratings, I divide the sample into two categories, Highrating (Morningstar Ratings $>$ 3) and Lowrating (Morningstar Ratings $<=3$ ), then I regress the empirical analysis with baseline model equation (3). Especially, robustness test also incorporates the Morningstar funds Ratings into the control variable of the overall analysis in China's mutual fundsmarket, and the equation formulation is based on the following specification:

$$
\begin{gathered}
\text { Flow }_{i, t}=a+b_{1} \operatorname{Perf}_{i, t}^{q u a}+b_{2} \operatorname{Perf}_{i, t}^{6 m}+b_{3} \operatorname{Perf}_{i, t}^{1 y r}+b_{4} \operatorname{Perf}_{i, t}^{3 y r}+\text { cMin_Rank }_{i, t} \\
+ \text { dMorningstarRating } \\
i, t
\end{gathered}
$$

The MorningstarRating ${ }_{i, t}$ represents fund $i$ 's rating based on Morningstar funds ratings scheme in quarter $\mathrm{t}$.

Table 3 presents the results of the regression with the Morningstar Ratings. Firstly, for Highrating funds and Lowrating funds, the coefficients of variable $\operatorname{Min}_{-} R_{a n k_{i, t}}$ are both positive and significant, but the magnitude of Lowrating funds is much larger the magnitude of Highrating funds. That means for Lowrating funds investment, fund flows display higher sensitivity to the minimum performance measure and the investors tend to place a greater weight on the worst signal than the Highrating funds, thus the investors become more sensitive and more willing to make the short term investment. That's can be the reason coefficient of $\operatorname{Perf} f_{i, t}^{q u a}$ is also higher in Lowrating funds. Besides, based on the results in column (3), the coefficient of variable MorningstarRating $_{i, t}$ is also positive, a one-star increase in Morningstar rating is associated with a fund flow increase. These results suggest that the Morningstar rating is an important signal for investors to make the decision in China's mutual funds market.

\begin{tabular}{|c|c|c|c|}
\hline & (1) & (2) & (3) \\
\hline VARIABLES & Highrating & Lowrating & Overall \\
\hline \multirow[t]{2}{*}{ Perf qua } & $0.0142 * * *$ & $0.0280 * * *$ & $0.0225 * * *$ \\
\hline & $(0.00186)$ & $(0.00174)$ & $(0.00130)$ \\
\hline \multirow[t]{2}{*}{ Perf $f^{6 m}$} & $0.00719 * * *$ & $-0.00298 * *$ & $0.000332 * *$ \\
\hline & $(0.00192)$ & $(0.00200)$ & $(0.00145)$ \\
\hline \multirow[t]{2}{*}{$\operatorname{Perf} f^{1 y r}$} & -0.00112 & $0.00329 *$ & $0.00287 * *$ \\
\hline & $(0.00170)$ & $(0.00187)$ & $(0.00143)$ \\
\hline \multirow[t]{2}{*}{$\operatorname{Perf} f^{3 y r}$} & $0.00145^{* *}$ & $0.0143 * * *$ & $0.000255^{* *}$ \\
\hline & $(0.00144)$ & $(0.00172)$ & $(0.00140)$ \\
\hline \multirow[t]{2}{*}{ Rank } & $0.000902^{* * *}$ & $0.00891 * * *$ & $0.00345^{* * *}$ \\
\hline & $(0.00224)$ & $(0.00292)$ & $(0.00199)$ \\
\hline \multirow[t]{2}{*}{ Age } & $-0.00242 * * *$ & $-0.000113 * *$ & $-0.00344 * *$ \\
\hline & $(0.000770)$ & $(0.000843)$ & $(0.00310)$ \\
\hline \multirow[t]{2}{*}{ Flow $w_{\text {previous }}$ quarter } & $0.121 * * *$ & $0.122 * * *$ & $0.0620^{* * *}$ \\
\hline & $(0.00683)$ & $(0.00666)$ & $(0.00516)$ \\
\hline \multirow[t]{2}{*}{ Volatility } & $-0.0524 * * *$ & $-0.0630^{* * *}$ & $0.132 * * *$ \\
\hline & $(0.00294)$ & $(0.00245)$ & $(0.0104)$ \\
\hline \multirow[t]{2}{*}{ MorningstarRating } & & & $0.000118^{* *}$ \\
\hline & & & $(2.62 \mathrm{e}-05)$ \\
\hline \multirow[t]{2}{*}{ Constant } & $-0.0145 * * *$ & $-0.0192 * * *$ & $-0.0440 * * *$ \\
\hline & $(0.00167)$ & $(0.00189)$ & $(0.00733)$ \\
\hline Observations & 6,588 & 7191 & 13779 \\
\hline R-squared & 0.119 & 0.121 & 0.108 \\
\hline Companycode Number & 1,532 & 1248 & 2201 \\
\hline
\end{tabular}

Table 3. Robustness test with consideration of morningstar ratings

Notes. $* * * \mathrm{p}<0.01, * * \mathrm{p}<0.05, * \mathrm{p}<0.1$. Standard errors in parentheses. 
Furthermore, the analysis may have the endogenous effect by the investors' loss aversion, to solve this situation, considering most investors will tend to be loss aversion when they choose mutual funds to invest, especially in the China's market with high uncertainty, thus I repeat the robustness test analysis by dividing sample into two categories in Table 4. The first is funds that minimum performance is positive ( Min_Rank $_{i, t} \geq 0$ ), and the second is funds that minimum performance is negative $\left(\operatorname{Min}_{-} \operatorname{Rank}_{i, t}<0\right)$. The first two columns of Table 4 present the results with positive minimum performance while the last two columns present negative minimum. We can find the results are qualitatively similar with the previous analysis and this robustness test analysis.

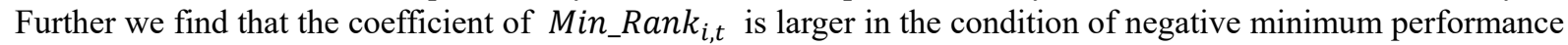
$\left(\right.$ Min_Rank $\left._{i, t}<0\right)$. That corresponds to the intuitive understanding that mutual fund investors will tend to be endogenously loss-aversion, thus they will place a greater weight on the worst signal during the negative performance period. In addition, we can also discuss the categories of mutual funds in China's market and take an deep research with different industries, we will leave these discussion to the future perspectives of our research.

Table 4. Robustness test with consideration of Morningstar Ratings and investors' loss aversion

\begin{tabular}{|c|c|c|c|c|}
\hline & (1) & (2) & (3) & (4) \\
\hline VARIABLES & Positive & Positive & Negative & Negative \\
\hline \multirow[t]{2}{*}{ Perf qua } & $0.000193 * *$ & $0.000173 *$ & $0.0312 * * *$ & $0.0301 * * *$ \\
\hline & $(0.00214)$ & $(0.00253)$ & $(0.00172)$ & $(0.00183)$ \\
\hline \multirow[t]{2}{*}{ Perf $f^{6 m}$} & $0.00237 * *$ & $0.00302 * *$ & $-0.00216^{*}$ & $-0.00114 *$ \\
\hline & $(0.00230)$ & $(0.00268)$ & $(0.00179)$ & $(0.00190)$ \\
\hline \multirow[t]{2}{*}{ Perf ${ }^{1 y r}$} & $0.000358^{*}$ & $0.00140 *$ & $0.00935^{* * *}$ & $0.0103 * * *$ \\
\hline & $(0.00206)$ & $(0.00255)$ & $(0.00175)$ & $(0.00206)$ \\
\hline \multirow[t]{2}{*}{ Perf ${ }^{3 y r}$} & $0.000403 * *$ & $0.0106^{* * *}$ & $0.0118 * * *$ & $0.0151 * * *$ \\
\hline & $(0.00199)$ & $(0.00316)$ & $(0.00129)$ & $(0.00200)$ \\
\hline \multirow[t]{2}{*}{ Rank } & $0.00234 * * *$ & $0.00254^{* *}$ & $0.0297 * * *$ & $0.0280^{* * *}$ \\
\hline & $(0.00261)$ & $(0.00319)$ & $(0.00355)$ & $(0.00441)$ \\
\hline \multirow[t]{2}{*}{ Age } & -0.001626 & $-0.0330 * * *$ & -0.00127 & $0.00969 *$ \\
\hline & $(0.000897)$ & $(0.00513)$ & $(0.000817)$ & $(0.00543)$ \\
\hline \multirow[t]{2}{*}{ Flow previous $_{\text {quarter }}$} & $0.0945^{* * *}$ & $0.0690 * * *$ & $0.0992 * * *$ & 0.00660 \\
\hline & $(0.00656)$ & $(0.00795)$ & $(0.00680)$ & $(0.00764)$ \\
\hline \multirow[t]{2}{*}{ Volatility } & $-0.0217 * * *$ & $-0.0480 * *$ & $-0.0825 * * *$ & $-0.0691 * * *$ \\
\hline & $(0.00285)$ & $(0.0382)$ & $(0.00318)$ & $(0.0130)$ \\
\hline \multirow[t]{2}{*}{ MorningstarRating } & & $8.15 \mathrm{e}-05^{* *}$ & & $0.000204 * * *$ \\
\hline & & $(3.39 \mathrm{e}-05)$ & & $(4.24 \mathrm{e}-05)$ \\
\hline \multirow[t]{2}{*}{ Constant } & $-0.00511 * *$ & $-0.0730 * * *$ & $-0.0123 * * *$ & $-0.0739 * * *$ \\
\hline & $(0.00205)$ & $(0.0116)$ & $(0.00186)$ & $(0.0132)$ \\
\hline Observations & 6,549 & 6,549 & 7,230 & 7,230 \\
\hline R-squared & & 0.030 & & 0.090 \\
\hline Companycode Number & 1,673 & 1,673 & 1,732 & 1732 \\
\hline
\end{tabular}

Notes. $* * * \mathrm{p}<0.01, * * \mathrm{p}<0.05, * \mathrm{p}<0.1$. Standard errors in parentheses.

\section{Conclusion}

This paper provides empirical evidence of ambiguity averse investors' behaviour in China's mutual funds market. The most important finding is that in China's mutual funds market, corresponding to the previous research about making decisions under ambiguity aversion (e.g., Epstein and Schneider, 2008, Antoniou, Harris and Zhang, 2015), the investors who face with signals of great uncertain quality, they will place great weight on the worst signal. To measure the worst signal, I use the data of return over the different time horizon, one quarter, six months, one year and three years. I use this performance returns as the multiple signals observed by investors about the mutual fund managers' skill.

I created a variable represent the mutual funds flows in China's mutual funds market, and the results report that fund flows display high sensitivity to the minimum performance measure. I also find that the Morningstar Ranking will also affect the investors' behaviour, the investors will behave more sensitive to the low rating mutual funds and the minimum performance. Furthermore, I distinguish the sample between the positive 
minimum performance and negative minimum performance. the empirical results indicate that during a negative performance period, investors will become more conservative and place more sensitivity to the minimum performance measure. To summarize, the results of this paper suggest that the ambiguity averse behaviour is substantial exist in China's mutual funds market, the findings could be significant suggestions for both managers and investors in China's mutual funds market.

\section{Acknowledgments}

Yuxiang Bian acknowledges support by China Scholarship Council.

\section{References}

Ahn, D., Choi, S., Gale, D., \& Kariv, S. (2014). Estimating ambiguity aversion in a portfolio choice experiment. Quantitative Economics, 5(2), 195-223. https://doi.org/10.3982/QE243

Antoniou, C., Harris, R. D., \& Zhang, R. (2015). Ambiguity aversion and stock market participation: An empirical analysis. Journal of Banking $\&$ Finance, 58, 57-70. https://doi.org/10.1016/j.jbankfin.2015.04.009

Ben-Rephael, A., Kandel, S., \& Wohl, A. (2012). Measuring investor sentiment with mutual fund flows. Journal of financial Economics, 104(2), 363-382. https://doi.org/10.1016/j.jfineco.2010.08.018

Bossaerts, P., Ghirardato, P., Guarnaschelli, S., \& Zame, W. R. (2010). Ambiguity in asset markets: Theory and experiment. The Review of Financial Studies, 23(4), 1325-1359. https://doi.org/10.1093/rfs/hhp106

Cao, H. H., Wang, T., \& Zhang, H. H. (2005). Model uncertainty, limited market participation, and asset prices. The Review of Financial Studies, 18(4), 1219-1251. https://doi.org/10.1093/rfs/hhi034

Carhart, M. M. (1997). On persistence in mutual fund performance. The Journal of finance, 52(1), 57-82. https://doi.org/10.1111/j.1540-6261.1997.tb03808.x

Chen, Z., \& Epstein, L. (2002). Ambiguity, risk, and asset returns in continuous time. Econometrica, 70(4), 1403-1443. https://doi.org/10.1111/1468-0262.00337

Cremers, K. M., \& Petajisto, A. (2009). How active is your fund manager? A new measure that predicts performance. The review of financial studies, 22(9), 3329-3365. https://doi.org/10.1093/rfs/hhp057

Del Guercio, D., \& Tkac, P. A. (2008). Star power: The effect of monrningstar ratings on mutual fund flow. Journal of Financial and Quantitative Analysis, 43(4), 907-936. https://doi.org/10.1017/S0022109000014393

Dimmock, S. G., Kouwenberg, R., Mitchell, O. S., \& Peijnenburg, K. (2016). Ambiguity aversion and household portfolio choice puzzles: Empirical evidence. Journal of Financial Economics, 119(3), 559-577. https://doi.org/10.1016/j.jfineco.2016.01.003

Dow, J., \& Da Costa Werlang, S. R. (1992). Uncertainty aversion, risk aversion, and the optimal choice of portfolio. Econometrica: Journal of the Econometric Society, 197-204. https://doi.org/10.2307/2951685

Easley, D., \& O'Hara, M. (2009). Ambiguity and nonparticipation: The role of regulation. The Review of Financial Studies, 22(5), 1817-1843. https://doi.org/10.1093/rfs/hhn100

Epstein, L. G., \& Schneider, M. (2007). Learning under ambiguity. The Review of Economic Studies, 74(4), 1275-1303. https://doi.org/10.1111/j.1467-937X.2007.00464.x

Epstein, L. G., \& Schneider, M. (2008). Ambiguity, information quality, and asset pricing. The Journal of Finance, 63(1), 197-228. https://doi.org/10.1111/j.1540-6261.2008.01314.x

Epstein, L. G., \& Schneider, M. (2010). Ambiguity and asset markets. Annu. Rev. Financ. Econ., 2(1), 315-346. https://doi.org/10.1146/annurev-financial-120209-133940

Froot, K. A., O'connell, P. G., \& Seasholes, M. S. (2001). The portfolio flows of international investors. Journal of financial Economics, 59(2), 151-193. https://doi.org/10.1016/S0304-405X(00)00084-2

Huang, J. C., Wei, K. D., \& Yan, H. (2012). Investor learning and mutual fund flows. In AFA 2012 Chicago meetings paper. http://dx.doi.org/10.2139/ssrn.972780

Huang, J., Wei, K. D., \& Yan, H. (2007). Participation costs and the sensitivity of fund flows to past performance. The journal of finance, 62(3), 1273-1311. https://doi.org/10.1111/j.1540-6261.2007.01236.x

Illeditsch, P. K. (2011). Ambiguous information, portfolio inertia, and excess volatility. The Journal of Finance, 66(6), 2213-2247. https://doi.org/10.1111/j.1540-6261.2011.01693.x 
Ju, N., \& Miao, J. (2012). Ambiguity, learning, and asset returns. Econometrica, 80(2), 559-591. https://doi.org/10.3982/ECTA7618

Kacperczyk, M., \& Seru, A. (2007). Fund manager use of public information: New evidence on managerial skills. The Journal of Finance, 62(2), 485-528. https://doi.org/10.1111/j.1540-6261.2007.01215.x

Klibanoff, P., Marinacci, M., \& Mukerji, S. (2005). A smooth model of decision making under ambiguity. Econometrica, 73(6), 1849-1892. https://doi.org/10.1111/j.1468-0262.2005.00640.x

Li, C. W., Tiwari, A., \& Tong, L. (2017). Investment decisions under ambiguity: Evidence from mutual fund investor behavior. Management Science, 63(8), 2509-2528. https://doi.org/10.1287/mnsc.2016.2432

Lynch, A. W., \& Musto, D. K. (2003). How investors interpret past fund returns. The Journal of Finance, 58(5), 2033-2058. https://doi.org/10.1111/1540-6261.00596

Petajisto, A. (2013). Active share and mutual fund performance. Financial Analysts Journal, 69(4), 73-93. https://doi.org/10.2469/faj.v69.n4.7

Polwitoon, S., \& Tawatnuntachai, O. (2006). Diversification benefits and persistence of US-based global bond funds. Journal of Banking \& Finance, 30(10), 2767-2786. https://doi.org/10.1016/j.jbankfin.2005.10.003

Polwitoon, S., \& Tawatnuntachai, O. (2008). Emerging market bond funds: a comprehensive analysis. Financial Review, 43(1), 51-84. https://doi.org/10.1111/j.1540-6288.2007.00186.x

Sialm, C., Starks, L. T., \& Zhang, H. (2015). Defined contribution pension plans: Sticky or discerning money? The Journal of Finance, 70(2), 805-838. https://doi.org/10.1111/jofi.12232

Sirri, E. R., \& Tufano, P. (1998). Costly search and mutual fund flows. The journal of finance, 53(5), 1589-1622. https://doi.org/10.1111/0022-1082.00066

\section{Copyrights}

Copyright for this article is retained by the author(s), with first publication rights granted to the journal.

This is an open-access article distributed under the terms and conditions of the Creative Commons Attribution license (http://creativecommons.org/licenses/by/4.0/). 